\title{
Ocena rządowego projektu nowelizacji ustawy - Prawo o postępowaniu przed sądami administracyjnymi oraz niektórych innych ustaw ${ }^{1}$
}

Assessment of the governmental Bill on Amendment of the Law on Proceedings before Administrative Courts Act and Some Other Acts: The reason for introducing amendments to statutes is the intention to adapt the concepts and requirements of administrative court proceedings to the ones contained in the Code of Civil Procedure. According to the author's opinion, the bill may be subject to further legislative procedures, however, with regard to the scope of the amendment's subject matter, some legal doubts arise in certain areas. The author points out, inter alia, that the proposed changes may cause temporary organizational difficulties in the administrative courts. In the author's opinion, introduction of a personal signature as one of the methods of authentication or signing of an electronic document will facilitate the preparation of electronic documents in the course of proceedings before administrative courts. The author also notes some inaccuracies and editorial errors in the bill.

Keywords: computerisation, bill, administrative courts

Słowa kluczowe: informatyzacja, projekt ustawy, sądy administracyjne

Doktor nauk prawnych, ekspert ds. legislacji BAS . beata.binkowska-artowicz@sejm.gov.pl

- https://orcid.org/0000-0002-9172-5458

\section{Przedmiot opinii}

Przedmiotem opinii jest szczegółowa analiza prawna rządowego projektu ustawy o zmianie ustawy - Prawo o postępowaniu przed sądami administracyjnymi (druk sejmowy $\mathrm{nr} 3260$ ); dalej: projekt lub ustawa zmieniająca.

1 Szczegółowa opinia prawna na temat rządowego projektu ustawy o zmianie ustawy - Prawo o postępowaniu przed sądami administracyjnymi oraz niektórych innych ustaw (druk sejmowy nr 3260) sporządzona 29 marca 2019 r. na zlecenie przewodniczącego Komisji Cyfryzacji, Innowacyjności i Nowoczesnych Technologii; BAS-WAP 546/19. Opinia stanowi rozwinięcie i uzupełnienie opinii z 14 marca 2019 r., BAS-WAP 493/19, sporządzanej w trybie pilnym. 
W projekcie przewidziano doprecyzowanie warunków elektronizacji postępowania przed sądami administracyjnymi, uregulowanego w ustawie z 30 sierpnia 2002 r. - Prawo o postępowaniu przed sądami administracyjnymi (t.j. Dz.U. 2018, poz. 1302; dalej: p.p.s.a.). Projekt ustawy zmieniającej obejmuje:

- zmianę ustawy - Prawo o postępowaniu przed sądami administracyjnymi (art. 1 ustawy zmieniającej), polegającą na: wykluczeniu z pojęcia pism sądowych dokumentów składanych na rozprawie, nałożeniu na strony obowiązku wskazania nr PESEL lub numeru identyfikującego podmiot we właściwym rejestrze, włączeniu radców Prokuratorii Generalnej Rzeczypospolitej Polskiej do kręgu pełnomocników upoważnionych do poświadczenia zgodności dokumentów z oryginałem oraz zobowiązanych do wzajemnego doręczania pism bezpośrednio i wprowadzeniu stosowania przepisów o niezbędnych kosztach postępowania w odniesieniu do radców Prokuratorii Generalnej Rzeczypospolitej Polskiej, wprowadzeniu obligatoryjnego upoważnienia dla Prezydenta RP do wydania rozporządzenia w sprawie sposobu i warunków przekazywania skargi, odpowiedzi na skargę oraz akt administracyjnych przez organ administracji do właściwego sądu administracyjnego, nałożeniu na strony obowiązku informowania sądu o każdej zmianie adresu elektronicznego, wprowadzeniu możliwości doręczania pism w postępowaniu sądowym i orzeczeń sądowych w formie dokumentu elektronicznego oraz możliwości utrwalenia w systemie teleinformatycznym sądu i opatrzenia kwalifikowanym podpisem elektronicznym notatki urzędowej z posiedzenia niejawnego, protokołu, orzeczeń sądowych i ich uzasadnień, a także wzmianek o ich sprostowaniu, wprowadzeniu możliwości przekazania sądowi przez organ administracji skargi oraz akt sprawy i odpowiedzi na skargę w postaci elektronicznej, wyłączeniu zwrotu akt administracyjnych prowadzonych w postaci elektronicznej,

- zmianę ustawy z 10 stycznia 2014 r. o zmianie ustawy o informatyzacji działalności podmiotów realizujących zadania publiczne oraz niektórych innych ustaw (Dz.U. poz. 183, ze zm.; dalej: ustawa z 10 stycznia 2014 r.) w części dotyczącej ustawy - Prawo o postępowaniu przed sądami administracyjnymi w zakresie elektronizacji postępowania (art. 2 ustawy zmieniającej), polegającą na: zamianie pojęcia „identyfikacja” na pojęcie „uwierzytelnienie” w odniesieniu do strony żądającej udostępniania akt sprawy w systemie teleinformatycznym sądu, wprowadzeniu obowiązku informowania strony o warunkach doręczeń za pomocą środków elektronicznych, wprowadzeniu możliwości podpisywania lub uwierzytelnienia dokumentów elektronicznych za pomocą kwalifikowanego podpisu elektronicznego, podpisu zaufanego albo podpisu osobistego, wprowadzeniu potwierdzenia wniesienia do sądu pisma w formie dokumentu elektronicznego poprzez przesłanie urzędowego poświadczenia odbioru, wprowadzenie upoważnienia Prezesa Naczelnego Sądu Administracyjnego do określenia wzorów dokumentów elektronicznych wykorzystywanych w postępowaniu przed sądami administracyjnymi i udostępnienia tych wzorów na stronie podmiotowej NSA, 
określeniu formy rezygnacji z doręczania pism za pomocą środków komunikacji elektronicznej, zmianie metod podpisania urzędowego poświadczenia odbioru pisma $\mathrm{w}$ formie dokumentu elektronicznego, określeniu minimalnego okresu dostępu do pisma $\mathrm{w}$ formie dokumentu elektronicznego dla jego adresata po dacie uznania pisma za doręczone,

- zmianę ustawy z 5 lipca 2018 r. o zmianie ustawy o usługach zaufania oraz identyfikacji elektronicznej oraz niektórych innych ustaw (Dz.U. poz. 1544, ze zm.; dalej: ustawa z 5 lipca 2018 r.); (art. 3 ustawy zmieniającej) poprzez: uchylenie art. 44, który w ustawie z 10 stycznia 2014 r. zastępował użyte w różnym przypadku wyrazy "podpisem potwierdzonym profilem zaufanym ePUAP” użytymi w odpowiednim przypadku wyrazami „podpisem zaufanym”; uchylenie pkt 5 w art. 69, który dotyczył wymienionego wyżej art. 44,

- zmianę ustawy z 6 grudnia 2018 r. o zmianie ustawy o dowodach osobistych oraz niektórych innych ustaw (Dz.U. 2019, poz. 60; dalej: ustawa z 6 grudnia 2018 r.); (art. 4 ustawy zmieniającej) poprzez uchylenie pkt $3 \mathrm{w}$ art. 45 oraz pkt 2 w art. 54, dotyczących art. 44 ustawy z 5 lipca 2018 r. (uchylonego w art. 3 pkt 1 ustawy zmieniającej),

- przepis międzyczasowy (art. 5 ustawy zmieniającej), z modyfikacją dotyczącą możliwości wyboru wnoszenia pism przez stronę oraz ich doręczania przez sąd za pomocą środków komunikacji elektronicznej (pkt 1), a także dotyczącą bezpośredniego działania obowiązku zawarcia w pierwszym piśmie wniesionym po 31 maja 2019 r. numeru PESEL lub innego numeru identyfikującego stronę (pkt 2),

- przepisy dostosowujące, dotyczące metody uwierzytelnienia strony w systemie teleinformatycznym sądu do czasu przyłączenia tego systemu do węzła krajowego identyfikacji elektronicznej (art. 6 ustawy zmieniającej) oraz dostosowania przez organ systemu elektronicznego zarządzania dokumentacją (art. 7 ustawy zmieniającej).

Wejście $\mathrm{w}$ życie ustawy zmieniającej jest przewidziane w dacie wejścia w życie art. 4 ustawy z 10 stycznia 2014 r., dotyczącego wyłącznie zmian w Prawie o postępowaniu przed sądami administracyjnymi, to jest 31 maja 2019 r. (art. 8 ustawy zmieniającej).

Przedmiotowy projekt stanowi wyjątek, o którym mowa w $\$ 91$ ust. 2 i ust. 3 „Zasad techniki prawodawczej”': W szczególnie uzasadnionych przypadkach, jeżeli jest to konieczne dla uniknięcia luki $w$ prawie, można wyjątkowo znowelizować przepisy zmieniajace ogłoszonej ustawy w okresie ich vacatio legis (ust. 2); Nowelizacje przepisów zmieniających, o której mowa $w$ ust. 2, wprowadza się w życie $z$ dniem wejścia w życie tych przepisów zmieniających (ust. 3).

Dzień wejścia w życie projektu określono na 31 maja 2019 r.

2 Załącznik do rozporządzenia Prezesa Rady Ministrów z 20 czerwca 2002 r. w sprawie „Zasad techniki prawodawczej”, t.j. Dz.U. 2016, poz. 283. 


\section{Uwagi do projektu ustawy}

Dokonanie w projekcie nowelizacji kilku ustaw (ustawy - Prawo o postępowaniu przed sądami administracyjnymi, ustawy z 10 stycznia 2014 r., ustawy z 5 lipca 2018 r., ustawy z 6 grudnia 2018 r.) nie budzi wątpliwości z uwagi na przesłankę niezbędności realizacji zamysłu prawodawcy ${ }^{3}$ polegającego na doprecyzowaniu przepisów dotyczących elektronizacji postępowania przed sądami administracyjnymi. Zachowana została zasada jednej funkcji ustawy nowelizującej, czyli ograniczenie się do wprowadzenia zmian w ustawach zmienianych, z uwzględnieniem przepisów dostosowujących i przejściowych ${ }^{4}$.

$\mathrm{W}$ art. 1 pkt 1 ustawy zmieniającej projektodawca dokonuje ujednolicenia pojęcia pisma strony w postępowaniu sądowoadministracyjnym (art. 45 p.p.s.a.) z pojęciem pisma strony w art. $125 \$ 1$ ustawy z 17 listopada 1964 r. - Kodeks postępowania cywilnego (t.j. Dz.U. 2018, poz. 1360, ze zm.; dalej: k.p.c.).

$\mathrm{W}$ art. 1 pkt 2 ustawy zmieniającej projektodawca wprowadza dodatkowy wymóg formalny pierwszego w sprawie pisma procesowego. Zgodnie z powyższym przepisem art. $46 \$ 2$ pkt 1 lit. b otrzyma brzmienie: numer PESEL strony wnoszacej pismo, będacej osoba fizyczna, oraz jej pełnomocnika lub przedstawiciela ustawowego, jeżeli go posiadaja. Zamiarem projektodawcy (wedle uzasadnienia załączonego do projektu) było zapewnienie jednoznacznej identyfikacji podmiotów, które zostaną zarejestrowane w systemie teleinformatycznym. W przypadku stron będących osobami fizycznymi i ich przedstawicieli ustawowych, jak również pełnomocników nieprofesjonalnych regulacja ta nie budzi wątpliwości pod warunkiem zapewnienia faktycznej integracji z rejestrem PESEL, za pomocą którego sąd administracyjny dokona weryfikacji podanego numeru PESEL. Jednakże w przypadku profesjonalnych pełnomocników osób fizycznych treść normy prawnej wyinterpretowanej z proponowanego przepisu może budzić wątpliwości. Po pierwsze, w korzystniejszej sytuacji prawnej znajdą się profesjonalni pełnomocnicy osób prawnych (np. spółek kapitałowych), którzy nie zostaną zobowiązani do wskazania swojego numeru PESEL. Po drugie, obowiązek podania numeru PESEL może okazać się problematyczny w świetle art. 5 ust. 1 lit. c rozporządzenia Parlamentu Europejskiego i Rady (UE) 2016/679 z 27 kwietnia 2016 r. w sprawie ochrony osób fizycznych w związku z przetwarzaniem danych osobowych i w sprawie swobodnego przepływu takich danych oraz uchylenia dyrektywy 95/46/WE (ogólne rozporządzenie o ochronie danych), (Dz.Urz. UE L 119, s. 1; dalej: RODO). Stosownie bowiem do powyższego artykułu RODO: dane osobowe musza być adekwatne, stosowne oraz ograniczone do tego, co niezbędne do celów, w których sa przetwarzane („minimalizacja danych”).

M. Błachut, W. Gromski, J. Kaczor, Technika prawodawcza, Warszawa 2008, s. 100.

4 Ibidem, s. 114. 
Nie ulega wątpliwości, że numer PESEL jest daną osobową w świetle art. 4 pkt 1 RODO [„,dane osobowe” oznaczaja wszelkie informacje o zidentyfikowanej lub możliwej do zidentyfikowania osobie fizycznej („osobie, której dane dotycza”); możliwa do zidentyfikowania osoba fizyczna to osoba, która można bezpośrednio lub pośrednio zidentyfikować, w szczególności na podstawie identyfikatora takiego jak [...] numer identyfikacyjny], ponieważ na jego podstawie w sposób jednoznaczny można ustalić tożsamość osoby fizycznej. Jednocześnie wydaje się, że cel przetwarzania danych profesjonalnego pełnomocnika (czyli jego jednoznaczna identyfikacja) mógłby zostać spełniony w równym stopniu przez odwołanie do numeru wpisu na krajowej liście profesjonalnych pełnomocników legitymujących się zdolnością postulacyjną przed sądami administracyjnymi. Listy takie są prowadzone odpowiednio przez Krajową Izbę Radców Prawnych ${ }^{5}$, Naczelną Radę Adwokacką , Krajową Izbę Doradców Podatkowych ${ }^{7}$ oraz Polską Izbę Rzeczników Patentowych ${ }^{8}$. Dostęp do powyższych wykazów jest bezpłatny i odbywa się online. Dodatkowo należy zauważyć, że podanie np. przez radcę prawnego lub doradcę podatkowego numeru PESEL nie eliminuje obowiązku posługiwania się przez niego numerem wpisu przy sporządzaniu pism procesowych.

Z uwagi na fakt, że radca Prokuratorii Generalnej RP z mocy art. 33 ust. 1 ustawy z 15 grudnia 2016 r. o Prokuratorii Generalnej Rzeczypospolitej Polskiej (Dz.U. poz. 2261, ze zm.) jest profesjonalnym zastępcą procesowym Skarbu Państwa, zawarte w art. 1 pkt 3 oraz art. 1 pkt 5 projektu propozycje włączenia tego pełnomocnika do kręgu profesjonalnych pełnomocników upoważnionych do samodzielnego poświadczania zgodności odpisu dokumentu z oryginałem (art. $48 \$ 3$ i 4 p.p.s.a.) oraz zobowiązanych do doręczania sobie nawzajem pism $\mathrm{w}$ postępowaniu sądowoadministracyjnym (art. $66 \$ 1$ zdanie pierwsze oraz $\$ 1 \mathrm{a}$ p.p.s.a.) nie budzą wątpliwości. Zmiany powyższe są zasadne i przyczynią się do przyspieszenia postępowania sądowego z udziałem radców Prokuratorii Generalnej RP. Logiczną konsekwencją uwzględnienia udziału radcy Prokuratorii Generalnej RP w postępowaniu sądowoadministracyjnym jest także treść art. 1 pkt 13 ustawy zmieniającej, dotyczącego zakresu niezbędnych kosztów postępowania sądowego, określonego w art. 205 p.p.s.a. Dodatkowo jednak, nowelizując ustawę - Prawo postępowania przed sądami administracyjnymi, z uwagi na możliwość reprezentowania Skarbu Państwa przez radców Prokuratorii Generalnej ustawodawca mógłby rozważyć, na wzór regulacji przyjętej w art. 327 k.p.c., wprowadzenie w art. $140 \$ 1$ oraz $\$ 3$ p.p.s.a. wyłączenia w zakresie udzielania

5 Https://rejestrradcow.pl/Home/Index [dostęp 28 marca 2019 r.].

6 Http://www.rejestradwokatow.pl/adwokat/ewidencja [dostęp 28 marca 2019 r.].

7 Https://krdp.pl/doradcy.php/wyszukaj [dostęp 28 marca 2019 r.].

8 Https://grab.uprp.pl/RzecznicyPatentowi/Strony\%20witryny/Wyszukiwanie\%20 rzecznika\%20patentowego.aspx [dostęp 28 marca 2019 r.]. 
wskazówek co do terminu i sposobu wniesienia środka odwoławczego również w odniesieniu do radcy Prokuratorii Generalnej RP.

Przedstawiona w art. 1 pkt 4 lit. a projektu propozycja nowelizacji art. 54 $\$ 2$ p.p.s.a. może budzić wątpliwości redakcyjne. O ile bowiem zamiarem projektodawcy był wybór pomiędzy postacią papierową a postacią elektroniczną akt sprawy, o tyle użycie spójnika „lub” ( $w$ postaci papierowej lub w postaci elektronicznej) oznacza w języku polskim zastosowanie tzw. alternatywy nierozłącznej, czyli w omawianym przypadku - dopuszczalności przekazania akt sprawy w obydwu postaciach. Jakkolwiek użycie spójnika „lub” jest stosowane powszechnie $\mathrm{w}$ języku potocznym do przedstawienia rozłącznego wyboru dwóch możliwości, w przypadku przepisu prawnego trafniejsze wydawałoby się użycie spójnika „albo”, oznaczającego alternatywę rozłączną. Analogiczne uwagi można odnieść do redakcji projektowanego przepisu art. 12a $\$ 1$ zdanie drugie p.p.s.a. (w brzmieniu nadanym ustawą z 10 stycznia 2014 r., która wchodzi w życie 31 maja 2019 r.), wprawdzie nie objętego przedmiotową nowelizacją, lecz także dotyczącego jej zakresu przedmiotowego (elektronizacja postępowania sądowoadministracyjnego).

W art. 1 pkt 4 lit. b projektu przewidziano dodanie do art. 54 p.p.s.a. jednostek redakcyjnych w postaci $₫ 5$, wprowadzającego obligatoryjne upoważnienie dla Prezydenta RP do wydania rozporządzenia dotyczącego sposobu i warunków przekazywania skarg przez organ, którego działanie, bezczynność lub przewlekłe postępowanie jest przedmiotem skargi, i $\$ 6$, dotyczącego wytycznych doprecyzowujących powyższe rozporządzenie. Przepis upoważniający należy ocenić pozytywnie w kontekście rozdziału 8 - „Przepisy upoważniające” załącznika do rozporządzenia Prezesa Rady Ministrów z 20 czerwca 2002 r. w sprawie „Zasad techniki prawodawczej”. Logiczną konsekwencję omawianego przepisu ustawy zmieniającej stanowi art. 2 pkt 1 lit. f projektu, w którym projektodawca proponuje (poprzez odesłanie do art. 4 pkt 9 lit. b ustawy z 10 stycznia 2014 r.) uchylenie w art. 54 p.p.s.a. paragrafów 2a-2c (przepisy w okresie vacatio legis) dotyczących trybu przekazywania skargi oraz akt administracyjnych (zakładanych i prowadzonych przez organ administracji) w zależności od postaci akt oraz formy skargi. Konsekwentnie, zasadne wydaje się proponowane na mocy art. 2 pkt 1 lit. g projektu uchylenie zmian w art. $55 \$ 1$ i $\$ 3$ p.p.s.a. (przepisy w okresie vacatio legis), odwołujących się do uchylonych paragrafów 2a-2c w art. 54 p.p.s.a.

Rozszerzenie w art. 1 pkt 6 ustawy zmieniającej zakresu przedmiotowego obowiązku zawiadomienia sądu o każdej zmianie adresu elektronicznego (art. 70 $\$ 1$ p.p.s.a.) stanowi logiczną konsekwencję wprowadzenia doręczeń za pomocą środków komunikacji elektronicznej. Jednakże projektodawca nie sprecyzował, że obowiązek zawiadamiania o zmianie adresu elektronicznego dotyczy jedynie sytuacji, w której strona już wskazała swój adres elektroniczny jako adres do doręczeń. Nie wydaje się bowiem racjonalne nakładanie na stronę postępowania 
obowiązku wskazywania zmian adresu elektronicznego w przypadku, gdy strona ta komunikuje się z sądem w sposób tradycyjny - za pośrednictwem operatora pocztowego.

Proponowane $\mathrm{w}$ art. 1 pkt 7 projektu wprowadzenie $\$ 2 \mathrm{w}$ art. 75 p.p.s.a. umożliwia sądowi administracyjnemu doręczanie pism i orzeczeń $w$ formie dokumentów elektronicznych, na wzór regulacji zawartej w art. $140 \$ 2$ k.p.c.

Na mocy art. 1 pkt 8 ustawy zmieniającej w art. 100 p.p.s.a. projektodawca zamierza dodać $\$ 3$ w brzmieniu: Notatka urzędowa może być utrwalona w systemie teleinformatycznym sq̨du i opatrzona kwalifikowanym podpisem elektronicznym, aby umożliwić sporządzanie notatki urzędowej z posiedzenia niejawnego (na którym nie zostanie wydane orzeczenie) w formie dokumentu elektronicznego.

Protokół z przebiegu posiedzenia jawnego będzie mógł zostać utrwalony $\mathrm{w}$ formie dokumentu elektronicznego na mocy art. $101 \S 3$ p.p.s.a. (art. 1 pkt 9 ustawy zmieniającej). Z kolei zgodnie z obowiązującym art. 105 zdanie pierwsze p.p.s.a.: Strony moga $w$ toku posiedzenia, a jeżeli nie były obecne, na najbliższym posiedzeniu, zwrócić uwage sądu na uchybienia przepisom postępowania, wnoszac o wpisanie zastrzeżenia do protokołu.

W tym kontekście należy zwrócić uwagę na art. 156 p.p.s.a. (art. 1 pkt 12 ustawy zmieniającej), do którego zaproponowano dodanie $₫ 2$ a, dotyczącego formy wzmianki o sprostowaniu w przypadku wyroku utrwalonego w systemie teleinformatycznym sądu i opatrzonego kwalifikowanym podpisem elektronicznym. Należy zauważyć, że racjonalne jest, aby naprawienie wadliwości wyroku (niedokładności, błędu pisarskiego, rachunkowego lub innej oczywistej omyłki) znalazło swe odzwierciedlenie w takiej samej formie, w jakiej utrwalono wyrok. Możliwość ta pozwoli na zachowanie spójności formy dokumentacji sądowej.

Z uwagi na to, że brak możliwości fizycznej ingerencji w treść dokumentu opatrzonego kwalifikowanym podpisem elektronicznym, również w przypadku zastrzeżenia do protokołu, który został utrwalony w systemie teleinformatycznym sądu i opatrzony kwalifikowanym podpisem elektronicznym rekomenduje się wprowadzenie $\mathrm{w}$ art. 105 p.p.s.a. regulacji analogicznej jak w art. $156 \S 2 \mathrm{a}$ p.p.s.a.

Wprowadzenie w art. $137 \$ 5$ p.p.s.a. możliwości utrwalania wyroku w systemie teleinformatycznym sądu oraz opatrzenia go kwalifikowanym podpisem elektronicznym (art. 1 pkt 10 projektu) stanowi zmianę analogiczną do rozwiązania przyjętego w art. $324 \$ 4$ k.p.c. Dodatkowo w art. $143 \$ 2$ p.p.s.a. projektodawca przewiduje także możliwość utrwalenia w ten sam sposób uzasadnienia wyroku (art. 1 pkt 11 projektu).

$\mathrm{Z}$ proponowanej treści art. $286 \$ 1$ 1a p.p.s.a. (wprowadzonego mocą art. 1 pkt 14 projektu) wynika, że jeśli akta administracyjne sprawy (czyli te, które dokumentują przebieg postępowania administracyjnego przed wszczęciem postępowania sądowego) są prowadzone w postaci elektronicznej, to organ administracji publicznej otrzymuje jedynie odpis orzeczenia ze stwierdzeniem prawo- 
mocności. Projektodawca nie określił formy, w jakiej sporządzony zostanie odpis orzeczenia. Wydaje się jednak, że skoro organ posiada elektroniczną skrzynkę podawczą i przekazał już akta w postaci elektronicznej, to z przyczyn ekonomiki procesowej (np. eliminacja wielodniowego oczekiwania na papierowe zwrotne potwierdzenie odbioru odpisu orzeczenia), to racjonalnym rozwiązaniem legislacyjnym będzie wprowadzenie doręczania odpisu orzeczenia ze stwierdzeniem prawomocności w formie dokumentu elektronicznego do elektronicznej skrzynki podawczej organu.

W art. 2 pkt 1 lit. a ustawy zmieniającej projektodawca dokonuje zamiany wyrazu „identyfikacja” na wyraz „uwierzytelnianie” w odniesieniu do czynności zmierzających do potwierdzenia w systemie teleinformatycznym tożsamości strony postępowania. Zmiana ta jest zasadna $\mathrm{z}$ uwagi na treść art. 3 pkt 5 rozporządzenia Parlamentu Europejskiego i Rady (UE) nr 910/2014 z 23 lipca 2014 r. w sprawie identyfikacji elektronicznej i usług zaufania w odniesieniu do transakcji elektronicznych na rynku wewnętrznym oraz uchylającego dyrektywę 1999/93/WE (Dz.Urz. UE L 257 z 2014 r., s. 73; dalej: rozporządzenie eIDAS), zgodnie z którym: „uwierzytelnianie” oznacza proces elektroniczny, który umożliwia identyfikacje elektroniczna osoby fizycznej lub prawnej, lub potwierdzenie pochodzenia oraz integralności weryfikowanych danych w postaci elektronicznej.

$\mathrm{W}$ art. 2 pkt 1 lit. b tiret pierwsze ustawy zmieniającej projektodawca dokonuje redakcyjnej zmiany polegającej na wprowadzeniu w art. $12 b$ p.p.s.a. (przepis w okresie vacatio legis) bezpośredniego odesłania do art. 16 ust. 3 ustawy z 17 lutego 2005 r. o informatyzacji działalności podmiotów realizujących zadania publiczne (t.j. Dz.U. 2017, poz. 570, ze zm.; dalej: ustawa z 17 lutego 2005 r.) $\mathrm{w}$ miejsce dotychczasowego piętrowego odesłania.

Pozytywnie należy ocenić dodanie $\$ 5 \mathrm{w}$ art. 12b p.p.s.a. (mocą art. 2 pkt 1 lit. $\mathrm{b}$ tiret drugie projektu). Zgodnie $\mathrm{z}$ tym przepisem przy doręczeniu stronie pierwszego pisma w sprawie w formie innej niż forma dokumentu elektronicznego na sądzie spoczywa obowiązek informacyjny w zakresie warunków wnoszenia do sądu oraz doręczania przez sąd pism za pomocą środków komunikacji elektronicznej. Obowiązek ten zrealizuje wskazany w uzasadnieniu projektu cel projektodawcy, polegający na rozpowszechnieniu wiedzy o możliwości wykorzystania środków komunikacji elektronicznej.

Zmiany wprowadzane na mocy art. 2 pkt 1 lit. c, lit. d oraz lit. e projektu dotyczą poświadczania zgodności odpisów dokumentów z oryginałem (art. $37 \$ 1 \mathrm{a}$ p.p.s.a., art. $48 \$ 3$ a p.p.s.a.), wystawienia dokumentu pełnomocnictwa (art. 37a p.p.s.a) oraz podpisania pisma (art. $46 \$ 2$ a p.p.s.a.) - każdorazowo w przypadku formy dokumentu elektronicznego. Wprowadzenie powyższych zmian nie budzi wątpliwości, gdyż zmiany te wynikają z konieczności dostosowania regulacji prawnych do istniejących metod uwierzytelniania. Analogiczne dostosowanie nastąpiło już w zakresie postępowania cywilnego. Równie niezbędna zmiana została zawarta w art. 2 pkt 1 lit. h tiret drugie ustawy zmieniającej, dotyczą- 
cym metody podpisania urzędowego poświadczenia odbioru (art. 74a $₫ 3$ pkt 2 p.p.s.a.).

Obecnie do omawianych metod uwierzytelniania należy kwalifikowany podpis elektroniczny, zdefiniowany w art. 3 pkt 12 rozporządzenia eIDAS: „kwalifikowany podpis elektroniczny" oznacza zaawansowany podpis elektroniczny, który jest składany za pomoca kwalifikowanego urzadzenia do składania podpisu elektronicznego i który opiera się na kwalifikowanym certyfikacie podpisu elektronicznego. Drugą z metod uwierzytelniania jest podpis zaufany, zdefiniowany w art. 3 pkt 14a ustawy z 17 lutego 2005 r.: podpis zaufany - podpis elektroniczny, którego autentyczność i integralność sa zapewniane przy użyciu pieczęci elektronicznej ministra właściwego do spraw informatyzacji, zawierajacy: a) dane identyfikujące osobę, ustalone na podstawie środka identyfikacji elektronicznej wydanego $w$ systemie, o którym mowa wart. 20aa pkt 1 [przepis odsyła do pojęcia tzw. systemu teleinformatycznego - dopisek A.B.-A.], obejmujace: imię (imiona), nazwisko, numer PESEL, b) identyfikator środka identyfikacji elektronicznej, przy użyciu którego został złożony, c) czas jego złożenia.

Trzecią metodą uwierzytelnienia jest podpis osobisty, który w świetle art. 2 ust. 1 pkt 9 ustawy z 6 sierpnia 2010 r. o dowodach osobistych (t.j. Dz.U. 2017, poz. 1464, ze zm.) jest zaawansowanym podpisem elektronicznym $\mathrm{w}$ rozumieniu art. 3 pkt 11 rozporządzenia eIDAS ${ }^{9}$, weryfikowanym za pomocą certyfikatu podpisu osobistego.

W tym miejscu należy zauważyć, że wprowadzenie podpisu osobistego ułatwi stronom, uczestnikom oraz ich pełnomocnikom procesowym sporządzanie dokumentów elektronicznych w postępowaniu sądowoadministracyjnym. Ustawa zmieniająca, dopuszczając podpis osobisty jako metodę uwierzytelniania dokumentów, umożliwi np. radcy prawnemu czy adwokatowi występującemu w sprawie wykorzystanie warstwy elektronicznej nowego dowodu osobistego (o ile przy składaniu wniosku o wydanie nowego dowodu osobistego wyrażono zgodę na umieszczenie w jego warstwie elektronicznej certyfikatu podpisu osobistego), bez konieczności posiadania kwalifikowanego podpisu elektronicznego czy tworzenia profilu zaufanego (niezbędnego do składania podpisu zaufanego). Mocodawcy (np. skarżący będący osobami fizycznymi) będą mogli również podpisywać dokument elektroniczny stwierdzający udzielenie pełnomocnictwa za

9 Zgodnie z tym przepisem, „zaawansowany podpis elektroniczny” oznacza podpis elektroniczny, który spełnia wymogi określone w art. 26 rozporządzenia eIDAS. Z kolei we wskazanym art. 26 prawodawca europejski przewiduje, że: [z]aawansowany podpis elektroniczny musi spetniać następujące wymogi: a) jest unikalnie przyporządkowany podpisującemu; b) umożliwia ustalenie tożsamości podpisującego; c) jest składany przy użyciu danych służacych do składania podpisu elektronicznego, których podpisujacy może, z duża doza pewności, użyć pod wyłaczną swoja kontrola; oraz d) jest powiązany $z$ danymi podpisanymi w taki sposób, że każda późniejsza zmiana danych jest rozpoznawalna. 
pomocą powszechnie dostępnego nowego dowodu osobistego. Udogodnienie to wydaje się także korzystne dla stron i uczestników postępowania nieposiadających profesjonalnej reprezentacji procesowej, którzy za pomocą funkcjonalności nowego dowodu osobistego będą mogli samodzielnie podpisywać pisma procesowe wytworzone w formie dokumentu elektronicznego.

W art. 49a p.p.s.a. (art. 2 pkt 1 lit. e ustawy zmieniającej) projektodawca przewiduje obowiązek wystawienia przez sąd urzędowego poświadczenia odbioru w rozumieniu ustawy z 17 lutego 2005 r. na wzór unormowań zawartych w art. $63 \$ 4$ zdanie drugie ustawy z 14 czerwca 1960 r. - Kodeks postępowania administracyjnego (t.j. Dz.U. 2018, poz. 2096; dalej: k.p.a.) oraz art. $168 \$ 4$ zdanie drugie ustawy z 29 sierpnia 1997 r. - Ordynacja podatkowa (t.j. Dz.U. 2018, poz. 800; dalej: o.p.).

Wprowadzenie na mocy art. 2 pkt 1 lit. e ustawy zmieniającej możliwości określenia przez Prezesa Naczelnego Sądu Administracyjnego niewiążących wzorów dokumentów elektronicznych (art. 49b p.p.s.a.) może ułatwić ich sporządzanie stronom, uczestnikom postępowania oraz ich pełnomocnikom. Udogodnienie może okazać się szczególnie korzystne dla stron nieposiadających profesjonalnej reprezentacji procesowej. Przyjęcie projektowanej regulacji może odnieść także pozytywne skutki dla samych sądów administracyjnych na etapie kwalifikacji pism procesowych, dokonywanych po wpływie korespondencji do sądu, a w efekcie w niektórych przypadkach może przyspieszyć postępowanie sądowoadministracyjne.

$\mathrm{W}$ art. $74 \mathrm{a} \$ 2$ p.p.s.a. (art. 2 pkt 1 lit. h tiret pierwsze ustawy zmieniającej) - przepis w okresie vacatio legis - zaproponowano dodanie zdania drugiego w brzmieniu: Oświadczenie o rezygnacji z doręczania pism za pomoca środków komunikacji elektronicznej składa się $w$ formie dokumentu elektronicznego. Nowelizacja ta ujednolica regulację formy oświadczenia na wzór przepisów postępowania cywilnego (art. $125 \$ 2^{4}$ zdanie pierwsze k.p.c.). Konsekwentnie - z uwagi na ogólną zasadę zaufania obywateli do państwa należy zarekomendować nowelizację również w zakresie wprowadzenia obowiązku zawarcia pouczenia o formie powyższego oświadczenia, np. w art. 74a $\$ 3$ p.p.s.a. (przepis w okresie vacatio legis), dotyczącym zawiadomienia przesyłanego na adres elektroniczny adresata $\mathrm{w}$ celu doręczenia pisma w formie dokumentu elektronicznego.

$\mathrm{W}$ art. $74 \mathrm{a} \$ 9$ p.p.s.a. (art. 2 pkt 1 lit. h tiret trzecie ustawy zmieniającej) projektodawca wprowadza minimalny trzymiesięczny okres dostępu dla stron do sporządzonego przez sąd pisma w formie dokumentu elektronicznego. Rozwiązanie to dotyczy fikcji prawnej, polegającej na przyjęciu (ze skutkiem prawnym), że pismo (mimo faktycznego nieodebrania przez adresata) zostało doręczone. Regulacja zakładająca możliwość dostępu adresata w systemie teleinformatycznym sądu do treści pisma jeszcze przez 3 miesiące po dacie uznania pisma za doręczone ułatwia podejmowanie czynności procesowych (np. wniesienia skargi kasacyjnej od wyroku czy złożenia zażalenia na postanowienie odmawiające 
wstrzymania wykonania zaskarżonej decyzji), ponieważ dopiero od daty uznania pisma za doręczone rozpoczyna się bieg terminów procesowych (co do zasady krótszych niż wskazany trzymiesięczny termin). Omawiane rozwiązanie prawne wyklucza sytuacje, w których strona, do której sąd skierował pismo w formie dokumentu elektronicznego, zwraca się do sądu w odrębnym piśmie z wnioskiem o doręczenie (jedynie w celach informacyjnych) pisma uznanego za doręczone. Dostrzeżenia wymaga, że analogiczne unormowania znajdują się w art. $46 \$ 8$ k.p.a. oraz w art. $152 \mathrm{a} \$ 5$ o.p.

W art. 2 pkt 2 projektu oraz w art. 5 pkt 1 projektu wprowadzono możliwość wyboru przez stronę postępowania wnoszenia i doręczania pism $\mathrm{w}$ formie dokumentów elektronicznych już od dnia wejścia w życie ustawy zmieniającej - to jest 31 maja $2019 \mathrm{r}^{10}$. Realizacja tej możliwości może spowodować czasowe trudności organizacyjne w sądach administracyjnych wynikające $\mathrm{z}$ konieczności szybszego przystosowania do nowej regulacji. Jednakże możliwość tę należy ocenić korzystnie z punktu widzenia strony postępowania (również uczestnika na prawach strony), która w toczącym się obecnie postępowaniu już od 31 maja $2019 \mathrm{r}$. np. z powodu zamieszkania w miejscowości znacznie oddalonej od siedziby sądu czy planowanego długoterminowego wyjazdu wyrazi wolę otrzymywania pism w sposób szybszy i niezależny od miejsca swojego pobytu lub zamierza wnieść pismo w dogodniejszej dla siebie formie dokumentu elektronicznego (bez konieczności nadania pisma w urzędzie pocztowym).

$\mathrm{W}$ art. 3 pkt 1 projektu zawarto przepis uchylający art. 44 ustawy z 5 lipca 2018 r. Nowelizacja ma charakter redakcyjny, ponieważ mocą przepisu uchylanego ustawodawca dokonywał zmiany w art. 4 ustawy z 10 stycznia 2014 r. Wszystkie zmiany uchwalone (jeszcze nie obowiązujące - przepis w okresie vacatio legis) mocą wymienionego wyżej art. 44 ustawy z 5 lipca 2018 r. zostają jednak wprowadzone mocą omawianej ustawy zmieniającej. Konsekwentnie projektodawca w art. 3 pkt 2 ustawy zmieniającej uchyla art. 69 pkt 5 ustawy z 5 lipca 2018 r., odsyłający wyłącznie do uchylanego art. 44 tej samej ustawy. Analogicznie również $\mathrm{w}$ art. 4 ustawy zmieniającej z powyższej przyczyny projektodawca uchyla art. 45 pkt 3 oraz art. 54 pkt 2 ustawy z 6 grudnia 2018 r.

Zgodnie $\mathrm{z}$ art. 5 pkt 2 ustawy zmieniającej pierwsze pismo wniesione przez stronę w danej sprawie po dniu wejścia w życie tej ustawy (czyli po 31 maja 2019 r.) powinno zawierać: numer PESEL strony wnoszacej pismo, będacej osoba fizyczna, oraz jej petnomocnika lub przedstawiciela ustawowego, jeżeli go posiadają. W odniesieniu do przedmiotowej regulacji aktualne pozostają uwagi wyrażone wcześniej. Podkreślenia wymaga to, że w przypadku wejścia w życie omawianego przepisu przejściowego w projektowanym brzmieniu ewentualny

${ }_{10} \mathrm{~W}$ przypadku art. 2 pkt 2 projektu omawiany przepis przejściowy odnosi się do zmian dotyczących ustawy - Prawo o postępowaniu przed sądami administracyjnymi i wprowadzanych ustawą z 10 stycznia 2014 r. 
brak wskazania numeru PESEL będzie mógł być usunięty na wezwanie zgodnie $\mathrm{z}$ zarządzeniem przewodniczącego wystosowane pod rygorem pozostawienia pisma bez rozpoznania (art. $49 \$ 1$ p.p.s.a.).

W art. 6 ustawy zmieniającej projektodawca zawarł przepis dostosowujący, regulujący metody uwierzytelniania strony obowiązujące do czasu przyłączenia systemu teleinformatycznego sądu do węzła krajowego identyfikacji elektronicznej (czyli do czasu stworzenia dalszej części krajowego schematu identyfikacji elektronicznej, o którym mowa w art. 21a ust. 1 ustawy z 5 września 2016 r. o usługach zaufania oraz identyfikacji elektronicznej, t.j. Dz.U. 2019, poz. 162). Powyższe oznacza, że do czasu przyłączenia systemu teleinformatycznego sądu do celów uwierzytelnienia strony postępowania nie będzie mogła być wykorzystywana warstwa elektroniczna nowego dowodu osobistego (podpis osobisty).

$\mathrm{W}$ art. 7 ustawy zmieniającej projektodawca przewidział obowiązek dostosowania przez organ, którego działanie, bezczynność lub przewlekłe postępowanie jest przedmiotem skargi, systemu elektronicznego zarządzania dokumentacją, o którym mowa $w$ art. $12 a \$ 2$ i 3 ustawy zmienianej $w$ art. 1 . Przedmiotowy przepis dostosowujący wprowadza tzw. piętrowe odesłanie, które w omawianym przypadku nie jest czytelne. $\mathrm{Z}$ obecnego brzmienia proponowanego przepisu można bowiem wyinterpretować normę, zgodnie z którą organ jest zobowiązany do dostosowania tego konkretnego systemu elektronicznego zarządzania dokumentacją, w którym są przetwarzane akta w postaci elektronicznej (art. 12a $\$ 2$ p.p.s.a. - przepis w okresie vacatio legis). Jednakże art. 12a $\$ 2$ p.p.s.a. dotyczy akt tworzonych w sądzie, a obowiązek dostosowania przez jakikolwiek organ administracji publicznej systemu elektronicznego zarządzania dokumentacją, z wykorzystaniem którego są przetwarzane akta sądowe, nie jest wykonalny. Przepis nie powinien pozostawiać wątpliwości co do intencji ustawodawcy, zwłaszcza że zawiera nakaz powinnego zachowania (obowiązek dostosowania systemu). Z tej przyczyny wydaje się, że dla celów przejrzystości regulacji pożądana byłaby zmiana omawianego art. 7 projektu poprzez wprowadzenie bezpośredniego odesłania do przepisów o narodowym zasobie archiwalnym i archiwach.

Nie budzi wątpliwości data wejścia w życie ustawy zmieniającej - 31 maja 2019 r. (art. 8 ustawy zmieniającej), przy założeniu, że ustawa zostanie ogłoszona nie później niż 17 maja 2019 r., czyli przy zachowaniu czternastodniowej vacatio legis (art. 4 ust. 1 ustawy z 20 lipca 2000 r. o ogłaszaniu aktów normatywnych i niektórych innych aktów prawnych, t.j. Dz.U. 2017, poz. 1523, ze zm.).

Wydaje się, że dla przejrzystości regulacji ustawodawca mógłby rozważyć wprowadzenie odesłania do art. 3 pkt 35 rozporządzenia eIDAS, zawierającego bezpośrednio wiążącą definicję dokumentu elektronicznego. Zgodnie z tym przepisem: „dokument elektroniczny” oznacza każda treść przechowywana w postaci elektronicznej, w szczególności tekst lub nagranie dźwiękowe, wizualne lub audiowizualne. 
$\mathrm{Z}$ art. 1 ust. 2 pkt 1 lit. e ustawy z 5 sierpnia 2010 r. o ochronie informacji niejawnych (t.j. Dz.U. 2018, poz. 412) wynika, że przepisy tej ustawy mają zastosowanie do sądów. Wymieniona ustawa zawiera rozdział 8 - Bezpieczeństwo teleinformatyczne, dotyczący m.in. akredytacji systemu teleinformatycznego, dokumentu szczególnych wymagań bezpieczeństwa, certyfikacji środków ochrony elektromagnetycznej przeznaczonych do ochrony informacji niejawnych o klauzuli „poufne” lub wyższej.

Sądy administracyjne rozpoznają m.in. sprawy dotyczące poświadczenia bezpieczeństwa oraz z zakresu ochrony informacji niejawnych. Nawet przy założeniu, że przewodniczący wydziału sądu administracyjnego na mocy $₫ 2$ projektowanego rozporządzenia Prezydenta Rzeczypospolitej Polskiej w sprawie sposobu postępowania $\mathrm{z}$ aktami spraw sądowoadministracyjnych $\mathrm{w}$ wojewódzkich sądach administracyjnych i Naczelnym Sądzie Administracyjnym ${ }^{11}$ we wskazanych wyżej sprawach każdorazowo dokona wyboru tworzenia akt sprawy w postaci papierowej, nie można wykluczyć, że skarżący wniesie pismo o dowolnej treści $\mathrm{w}$ formie dokumentu elektronicznego (np. odnoszące się do zawartości akt administracyjnych sprawy) lub wystąpi do sądu o doręczanie pism za pomocą środków komunikacji elektronicznej. Nowelizując ustawę - Prawo o postępowaniu przed sądami administracyjnymi w zakresie elektronizacji postępowania, ustawodawca mógłby rozważyć dodanie przepisu stwierdzającego brak kolizji tejże ustawy z ustawą z 5 sierpnia 2010 r. o ochronie informacji niejawnych. Przykładowo, proponowany przepis ustawy - Prawo o postępowaniu przed sądami administracyjnymi mógłby otrzymać brzmienie: „Przepisy niniejszej ustawy nie naruszają przepisów ustawy z dnia 5 sierpnia 2010 r. o ochronie informacji niejawnych". Z kolei wyłączenie możliwości składania dokumentów w sprawach dotyczących poświadczenia bezpieczeństwa oraz z zakresu ochrony informacji niejawnych $\mathrm{w}$ formie dokumentu elektronicznego mogłoby budzić wątpliwości natury konstytucyjnej, związane z zasadą równości wobec prawa. Strona postępowania, która zamierza złożyć pismo w formie pisemnej, znajdowałaby się bowiem w lepszej sytuacji niż strona korzystająca ze środków komunikacji elektronicznej.

$\mathrm{W}$ art. $64 \mathrm{c} \$ 7$ p.p.s.a. ustawodawca przewidział, że: [j]eżeli organ nie przekazat sadowi sprzeciwu od decyzji, mimo wymierzenia grzywny, sad rozpoznaje sprawe na podstawie nadesłanego przez skarżacego odpisu sprzeciwu od decyzji. W art. 47 $\$ 3$ zdanie pierwsze p.p.s.a (przepis w okresie vacatio legis) ustawodawca wyłączył konieczność składania odpisów w przypadku pism wnoszonych w formie dokumentu elektronicznego. Nie jest jednak jasne, na jakiej podstawie sąd rozpozna sprzeciw, który zostanie złożony w formie dokumentu elektronicznego do elektronicznej skrzynki podawczej organu administracji, ale nie zostanie przeka-

11 Upoważnienie ustawowe znajduje się w art. 12a $\$ 8$ p.p.s.a. o treści ustalonej w art. 4 ustawy z 10 stycznia 2014 r., który będzie obowiązywał od dnia 31 maja 2019 r. 
zany sądowi zgodnie z art. 64c $\$ 4$ p.p.s.a. Konsekwentnie - w celu usunięcia luki w regulacji zasadna wydaje się nowelizacja niniejszą ustawą zmieniającą również art. 64c $\$ 7$ p.p.s.a. poprzez dodanie treści normatywnej dotyczącej odpisu sprzeciwu w formie dokumentu elektronicznego ${ }^{12}$ oraz ujęcie w omawianym przepisie treści normatywnej, według której w przypadku sprzeciwu składanego w formie dokumentu elektronicznego nie stosuje się przepisu art. $47 \$ 3$ zdanie pierwsze p.p.s.a.

$\mathrm{W}$ art. 285e $\$ 2$ zdanie drugie p.p.s.a. przewidziano obowiązek dołączania do skargi o stwierdzenie niezgodności z prawem prawomocnego orzeczenia dwóch odpisów przeznaczonych do akt Naczelnego Sądu Administracyjnego. Z uwagi na wskazywane już w niniejszej opinii wyłączenie obowiązku składania odpisów w przypadku pism wnoszonych w formie dokumentu elektronicznego (art. 47 $\$ 3$ zdanie pierwsze p.p.s.a.) oraz celem zapewnienia przejrzystości regulacji ustawodawca mógłby rozważyć w treści normatywnej zawartej w art. 285e $₫ 2$ zdanie drugie p.p.s.a. uwzględnienie skargi złożonej w formie dokumentu elektronicznego.

Na marginesie niniejszej analizy warto odnotować, że w art. 58 projektu rządowego z 12 lutego 2019 r. ustawy o elektronizacji doręczeń oraz o zmianie niektórych innych ustaw (numer projektu UD462, planowany termin przyjęcia projektu przez Radę Ministrów - I kwartał 2019 r. $^{13}$ ) przewidziano zmiany art. 12b p.p.s.a, art. $37 \$ 1$ la p.p.s.a., art. 37 a p.p.s.a., art. $46 \$ 2$ a p.p.s.a. oraz art. 66 p.p.s.a., zmienianych przedmiotową ustawą zmieniającą. W projekcie przewidziano również uchylenie art. 74a p.p.s.a., zmienianego przedmiotową ustawą zmieniającą.

\section{Podsumowanie}

- Rządowy projekt ustawy o zmianie ustawy - Prawo o postępowaniu przed sądami administracyjnymi może być przedmiotem dalszych prac legislacyjnych.

- Wątpliwości prawne w odniesieniu do zakresu przedmiotowego projektu występują w obszarach: przetwarzania przez sąd administracyjny numeru PESEL profesjonalnego pełnomocnika, braku doprecyzowania formy odpisu wyro-

12 O odpisach w formie dokumentu elektronicznego oraz sposobie ich poświadczania mowa jest m.in. w art. 194a $\$ 2$ a o.p.: Jeżeli odpis dokumentu został sporzadzony $w$ formie dokumentu elektronicznego, poświadczenia jego zgodności z oryginałem, o którym mowa $w \$ 2$, dokonuje się przy użyciu kwalifikowanego podpisu elektronicznego, podpisu zaufanego albo podpisu osobistego. Odpisy dokumentów poświadczane elektronicznie sq sporzadzane $w$ formatach danych określonych w przepisach wydanych na podstawie art. 18 pkt 1 ustawy $z$ dnia 17 lutego 2005 r. o informatyzacji działalności podmiotów realizujących zadania publiczne.

13 Https://bip.kprm.gov.pl/kpr/form/r6206899351,Projekt-ustawy-o-elektronizacji-doreczen-oraz-zmianie-niektorych-innych-ustaw.html [dostęp 28 marca 2019 r.]. 
ku doręczanego organowi po stwierdzeniu prawomocności orzeczenia, braku obowiązku pouczenia o formie oświadczenia o rezygnacji z doręczania pism za pomocą środków komunikacji elektronicznej, braku wyłączenia radców Prokuratorii Generalnej w zakresie udzielania pouczenia o terminie i sposobie wnoszenia środka odwoławczego, braku wymogu formy dokumentu elektronicznego $\mathrm{w}$ przypadku zastrzeżenia do protokołu utrwalonego $\mathrm{w}$ systemie teleinformatycznym sądu i opatrzonego kwalifikowanym podpisem elektronicznym; relacji ustawy - Prawo o postępowaniu przed sądami administracyjnymi do przepisów ustawy o ochronie informacji niejawnych; braku obowiązku zawarcia pouczenia o formie oświadczenia o rezygnacji z doręczania pism za pomocą środków komunikacji elektronicznej; luki regulacyjnej w zakresie orzekania przez sąd na podstawie odpisu sprzeciwu od decyzji w przypadku, gdy sprzeciw został złożony $w$ formie dokumentu elektronicznego.

- Wprowadzenie podpisu osobistego jako jednej z metod uwierzytelnienia lub podpisywania dokumentu elektronicznego ułatwi sporządzanie dokumentów elektronicznych w postępowaniu sądowoadministracyjnym z uwagi na dopuszczenie wykorzystania warstwy elektronicznej nowego dowodu osobistego.

- Możliwość wyboru przez stronę postępowania wnoszenia i doręczania pism $\mathrm{w}$ formie dokumentów elektronicznych już od dnia wejścia w życie ustawy zmieniającej może spowodować czasowe trudności organizacyjne w sądach administracyjnych wynikające z konieczności szybszego przystosowania do nowej regulacji. Jednakże z punktu widzenia stron postępowania możliwość tę należy ocenić zdecydowanie korzystnie.

- Uwagi o charakterze redakcyjnym dotyczą: spójnika „lub” w odniesieniu do wyboru postaci akt przekazywanych sądowi przez organ administracji; niewyłączenia wprost wymogów formalnych w postaci odpisów skargi o stwierdzenie niezgodności z prawem prawomocnego orzeczenia w przypadku skargi składanej w formie dokumentu elektronicznego.

- Liczne zmiany przewidziane $\mathrm{w}$ omawianej ustawie nowelizującej wynikają z zamiaru dostosowania pojęć oraz wymogów postępowania sądowoadministracyjnego do postępowania uregulowanego w Kodeksie postępowania cywilnego. - W rządowym projekcie ustawy o elektronizacji doręczeń oraz o zmianie niektórych innych ustaw przewidziano m.in. zmiany dotyczące przepisów nowelizowanych omawianą ustawą.

\section{Bibliografia}

Błachut M., Gromski W., Kaczor J., Technika prawodawcza, Warszawa 2008. 